\title{
Beyond Nintendo: design and assessment of educational video games for first and second grade students
}

\author{
Ricardo Rosas ${ }^{\mathrm{a}, *}$, Miguel Nussbaum ${ }^{\mathrm{b}}$, Patricio Cumsille ${ }^{\mathrm{a}}$, Vladimir Marianov ${ }^{\mathrm{b}}$, \\ Mónica Correa ${ }^{a}$, Patricia Flores ${ }^{a}$, Valeska Grau ${ }^{a}$, Francisca Lagos ${ }^{a}$, \\ Ximena López ${ }^{\mathrm{a}}$, Verónica López ${ }^{\mathrm{a}}$, Patricio Rodriguez ${ }^{\mathrm{b}}$, Marcela Salinas ${ }^{\mathrm{a}}$

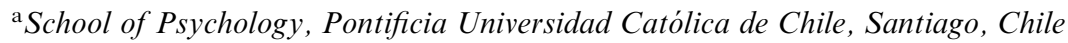 \\ ${ }^{\mathrm{b}}$ School of Engineering, Pontificia Universidad Católica de Chile, Santiago, Chile
}

Received 14 January 2002; accepted 29 July 2002

\begin{abstract}
The main objective of this study was to evaluate the effects of the introduction of educational videogames into the classroom, on learning, motivation, and classroom dynamics. These effects were studied using a sample of 1274 students from economically disadvantaged schools in Chile. The videogames were specifically designed to address the educational goals of the first and second years of school, for basic mathematics and reading comprehension. The sample was divided into experimental groups (EG), internal control groups (IC) and external control groups (EC). Students in the EG groups, used the experimental video games during an average of $30 \mathrm{~h}$ over a 3-month period. They were evaluated on their acquisition of reading comprehension, spelling, and mathematical skills, and on their motivation to use video games. Teachers' expectations of change due to the use of video games, their technological transfer, and handling of classroom dynamics, were assessed through ad hoc tests and classroom observations. The results show significant differences between the EG and IC groups in relation to the EC group in Math, Reading Comprehension and Spelling, but no significant differences in these aspects were found between the EG and the IC groups. Teacher reports and classroom observations confirm an improvement in motivation to learn, and a positive technological transfer of the experimental tool. Although further studies regarding the effects of learning through videogame use are imperative, positive effects on motivation and classroom dynamics, indicate that the introduction of educational video games can be a useful tool in promoting learning within the classroom.
\end{abstract}

(C) 2002 Elsevier Science Ltd. All rights reserved.

* Corresponding author.

E-mail address: rrosas@puc.cl (R. Rosas). 


\section{Introduction}

\subsection{Playing, learning and cognitive development}

Play, in its diverse forms, constitutes an important part of children's cognitive and social development (Csikszentmihaly, 1990; Provost, 1990; Rogoff, 1993).

In the context of cognitive development, playing is considered fundamental to the stabilizing processes that are essential for the development of cognitive structures. It is indiscernible for cognitive development by way of assimilation and accommodation processes. Through playing, children rehearse basic cognitive operations such as conservation, classification and reversibility (Piaget, 1951).

Playing is above all, a privileged learning experience. As Vigotsky (1979) states, a child learns through playing with others, creating and improving his or her zone of proximal development, because playing often involves more complex activities than those the child experiences in daily life. In correspondence with this idea are Bruner's (1986) findings that children normally use more complex grammatical structures while playing than they do in real life situations. As such, playing offers the cognitive support needed to develop higher order mental processes.

Playing initiates the symbolic use of objects and is therefore considered the first form of symbolization (Piaget, 1951). Thus, playing constitutes the first step towards abstract thinking (Vigotsky, 1976).

Games are a common form of playing. All games have properties, rules and procedures that must be mastered in order to become a "player". The understanding of the underlying concepts of games plays an important organizing role in cognition, similar to that of a story schema (Schank, 1990), in that it requires a mental framework which includes goals, conditions, players, and resolutions. Since playing games is a natural activity for children it is considered an excellent example of situated or "anchored" learning through authentic situations (Choi \& Hannafin, 1995; Herrington \& Oliver, 1999; Rogoff, 1993).

Playing changes as children grow up, following the course of cognitive development. The games played, their rules and meanings change as a child grows up. Once a child reaches school age, she or he is able to understand and follow the rules involved in structured games. Even though such rules are also present in learning situations found in a school setting, teachers usually view them as different and tend to separate school from play (Rieber, 1996).

The aforementioned is questionable, since the cognitive processes involved in learning are similar to and are based on those involved in playing (e.g. meaning, self-regulation, incidental learning, conceptualization, motivation and higher-order processing). In this context, using educational contents in game formats in school has the advantage of following the natural course of children's learning (Fitzgerald, 1991; Institute for Learning Sciences, 1994).

Of course games are currently used in the classroom; many socio-dramatic and rule-based games have been incorporated in the classroom. However, the incorporation of games through computer technology still creates resistance. This resistance is based on (1) teachers' perceptions of games as merely entertaining and not as useful instructional tools, (2) teachers' lack of knowledge and skills with respect to computer assisted instruction), and (3) insufficient developments of effective educational hardware and software (Bennet, Wood, \& Rogers, 1997; Rieber, 1996). 


\subsection{Computer games as instructional tools}

Why introduce computer games in schools? Important arguments are that it makes learning meaningful to students (Ausubel, Novak, \& Hanesian, 1983) and that it creates a learning culture that is more in correspondence with students' interests (Papert, 1980; Provenzo, 1992). In order to do so, the tools used to teach must approach students from an angle that seems interesting and relevant to them (Kafai, 1995; Provenzo, 1991).

There is ample empirical evidence supporting the positive effects of computer games as instructional tools (Knezek, 1997; Kulik, 1994), indicating that they strengthen and support:

School achievement: they favor a better performance in algebra (McFarlane, Sparrowhawk, \& Heald, 2002), increase reading comprehension (McFarlane et al., 2002), spelling and decoding of grammar (Din \& Caleo, 2000). The results of several meta-analyses indicate an overall positive effect of learning with computer games on student achievement, on attitudes towards learning, and on self-concept, when compared to traditional instruction (Lou, Abrami, \& d'Apollonia, 2001).

Cognitive abilities: using computer games favors the development of complex thinking skills related to problem solving (Keller, 1992), strategic planning (Jenkins, 2002; Keller, 1992; Mandinach, 1987; McFarlane et al., 2002) and self-regulated learning (Rieber, 1996; Zimmerman, 1990). Computer games also enable the development of different learning styles, since speed and level difficulty can be adjusted according to the player (Fitzgerald, 1991; Jenkins, 2002). They even facilitate language acquisition in students with learning disabilities (Nussbaum, Rosas, Rodríguez, Sun, \& Valdivia, 1999).

Motivation towards learning: a positive influence of computer games on students' motivation has also been found, reportedly more positive than the influence of traditional teaching methods (Kulik, 1994; McFarlane et al., 2002). This may be explained by the fact that these technologies have specific features that increase motivation to learn. They are attractive in that they present challenge, curiosity, and control over what is happening to the individual student (Jenkins, 2002; Lepper \& Malone, 1987). Another explanation is the decrease of verbalized erros, since computer games normally correct mistakes without emphasizing them (Institute for Learning Sciences, 1994).

Attention and concentration: an increase in motivation is directly related to children's attention and concentration (McFarlane et al., 2002). The Institute for Learning Sciences (1994) reports that students who use educational software spend more of their potential learning time concentrated, and that this is more evident in students with attention problems and low achievement.

As McFarlane et al. (2002) state, "computer games provide a forum in which learning arises as a result of tasks stimulated by the content of the games, knowledge is developed through the content of the game, and skills are developed as a result of playing the game" (p. 4).

Not all computer games produce the same effects; they play a different role depending on the type of programs and their characteristics. Tutorial programs - those used to teach students directly through information, demonstration and practise opportunities - seem to play a greater role in motivating students (Reeves, 1998); while drill-and-practise programs produce higher achievement gains in students (Coley, Cradler, \& Engel 2000; Sivin-Kachala \& Bialo, 1994). 
Programs offering exploratory environments - databases, simulations, hypermedia-based programs - enable students to take active control over their learning (Reeves, 1998).

Certain key design features of computer games are found to affect student learning more strongly. Among them: (1) adequate and adaptive feedback, (2) the embedding of cognitive strategies such as repetition, rehearsal, paraphrasing, outlining, cognitive mapping, and the drawing of analogies and inferences, and (3) animated graphics, which increase achievement and/or reduce task time (Azevedo \& Bernard, 1995; Sivin-Kachala \& Bialo, 1994).

Computer-assisted education brings benefits, not only to students, but also to their teachers. Through educational technology teachers can experiment with alternative methods of teaching that are related more closely to the individual student's needs and presented in contexts that are not traditionally associated with school learning. They also give more precise and timely feedback without emphasizing mistakes (Fitzgerald, 1991). "(Computer) games offer teachers enormous resources they can use to make their subject matter come alive for their students, motivating learning, offering rich and compelling problems, modeling the scientific process and the engineering context and enabling more sophisticated assessment mechanisms" (Jenkins, 2002, p. 3).

Incorporating computer games is an appealing way of producing and complementing a learning environment. However, some issues on its implementation in the school system impede its full use, among them:

Coverage: United States has a high penetration of computers in the educational environment, four million computers are currently installed in schools, and the rate of students per computers decreased from 125 students in 1984, to 10 in the year 2000 (Coley et al., 2000). However, the forecast for developing countries is not encouraging. Chile, considered a leader in Latin America when it comes to the incorporation of computer technology in the school system, has a rate of 45 students per computer in the year 2002, and plans on decreasing this rate to 30 students by the year 2005 (Lagos, 2002).

Teacher resistance towards a technology-centered learning environment: the physical assets of today's feasible computers -mainly its volume and weight- do not allow an easy and comfortable use of computers within the classroom environment, much less placed on top of students' desks. Usually, computers are placed together in a separate room that becomes the "technological learning space", separated from classrooms. Children in developing countries seldom visit these technological spaces due to teachers' resistance towards computer technology. In other words, the message given to students is that computers, much less computer games, should not be placed in the classroom and therefore do not form part of the classroom learning environment (Knezek, 1997). The aforementioned implies that computers do not always promote a permanent learning culture within the classroom (Clark, 1983), and therefore do not always produce the positive effects reported. Within this context, computer games tend to lose their potential as an instructional tool.

The complexities of edutainment: the industry dedicated to the design of educational software, edutainment $^{1}$, has focused on the elaboration of the educational contents involved, supposing that these will seem attractive to children just because they incorporate technology. Edutainment

\footnotetext{
1 McFarlane et al. (2002) define edutainment as "activities structured with a view of loosely supporting education, usually a combination of activities and games with an overtly educational content" (p. 8).
} 
is undoubtedly entertaining but generally lacks those game aspects that are so attractive to children, since the pedagogical task involved is more prominent than playing. As Hubbard (1991) states, " ... It is only when the problem to be solved, competition, timing and/or scoring raise immediate and interesting challenges - from the learners' perspective, "fun" - that a game, rather than a pedagogical exercise, has been created" (p. 221). Jensen (2002), Director of the Program in Comparative Media Studies at MIT, argues that "most existing edutainment products combine the entertainment value of a bad lecture with the educational value of a bad game" (p. 1). Besides the intrinsic difficulties of edutainment, an additional problem for developing nations like those in Latin America, is that there is very little software designed in, or translated into, the local language, much less software in accordance with their own school curriculum (Soloway, 1998).

\subsection{Video games in the classroom: an educational opportunity}

The challenge is therefore, to create ease to use, portable hardware with instructional and entertaining software (Garret \& Ezzo, 1996), aligned with the school curriculum, that children can use regularly in the classroom so as to create conditions which favor learning (attention, concentration, motivation to learn), effectively improve learning itself (Gros, 2000), and thus promoting learner-centered classrooms (Driscoll \& Rowley, 1997).

There are many alternatives to pursue this goal. One of them is the use of video games, with educational contents, inside the classroom as an instructional medium. With sales of approximately $\$ 4$ billion in 1990 and $\$ 8$ billion in the year 2000, video games are clearly a preferred game for children who reach game-playing age. They dominate much of the toy industry and have become a cultural and social force that shape children and adolescents' lifestyles (Provenzo, 1991). In this sense, incorporating educational computer games in the classroom and offering it as an educational resource to a generation already labeled the video generation (Provenzo, 1992), is certainly a hurdle that should be taken.

What makes video games effective? The most highlighted features are: (1) a clear goal: almost all video games are goal-oriented; that is, they have a clear and specific goal that children must try to reach (e.g. capturing the princess, reaching a destination), (2) adequate level of complexity, not too low but not too high; well-designed games are highly challenging and are rarely totally mastered, (3) high speed: most video games have a much faster speed than traditional mechanical games, (4) incorporated instructions: in most video games, children understand instructions while playing the game and do not need to read instructions, (5) independence from physical laws: video games normally do not follow the physical laws of the universe; objects can fly, spin, change shape or color as they please, and (6) holding power: they capture players' attention and continue to do so as the game builds a microworld with its own rules and regulations (Malone, 1980; Provenzo, 1991; Turkle, 1984).

However, the general use of video games has opponents who warn against their use based on supposed and/or proven negative effects. The most commonly studied are:

Aggression: most video games are at least aggressive, if not explicitly violent. This generally involves physical and verbal aggression among main characters. These aggressive actions and 
behaviors are said to provoke aggressive behavior in children who play them; an "acting out" reaction. Studies on the effect of video game use related to aggression confirm significant correlations between the use of video games and aggressive behavior on the short and intermediate term. Recent research suggests that exposure to violent video games does lead to an increase in aggressive behavior. Studies have shown that children exposed to violent video games show more hostile conduct than those exposed to non-violent video games, and these in turn show more hostile conduct than children not exposed to video games (Ballard \& Wiest, 1995; Cesarone, 1994, 2000; Kirsh, 1997, 1998).

Gender Bias: video games are also said to reflect gender stereotypes that favor masculinity. These effects have been proven, since video games tend to cast women as victims who are acted upon, rather than as initiators of action (Cesarone, 1994).

Immersion effect: video game playing is said to produce an alienating effect over players, who develop an "electronical autism" that hinders social and academic development. Little support can be found to sustain the idea that video game playing reduces participation in sports activities and is related to poor school performance (Egli \& Meyers, 1984). Others suggest that video game playing actually provide adolescents with a vehicle for fantasy that can help promote growth (Kestenbaum \& Weinstein, 1985). In fact, the immersion effect produced while playing video games promotes attention and concentration, processes extremely relevant for learning (Egli \& Meyers, 1984).

Why then use video games as an instructional tool? Because they also posses the positive elements found in computer games in general, and add value in that they create a microworld of their own, which players act on based on their natural tendencies towards learning (Rieber, 1996). Therefore, learning occurs while playing video games (Baird \& Silvern, 1990). Video games model not only the principles, but also the dynamics of cognitive processes, particularly the dynamics of complex systems. Even the programming of video games is considered a highly valuable tool for the development of higher order skills (Kafai, 1997).

The learning process that occurs while playing video games has to do with the immersion effect created (Hubbard, 1991), that is, an environment into which the players submerge themselves, progressively increasing their levels of attention and concentration on the goal to obtain. This immersion effect can be related to Csikszentmihalyi's flow theory (1990), defined as a state in which satisfaction occurs while one is "absorbed" by a certain activity. This effect has commonly been interpreted as alienating; however, it can be understood as a genuine opportunity to take advantage of children's concentration introducing educational contents (Lepper \& Malone, 1987).

What elements must a video game have in order to become an instructional tool? Enjoyable educational programs must include elements of (1) challenge: clear, meaningful and multiple goals, uncertain outcomes, variable difficulty levels, randomness, and constant feedback, (2) fantasy: a character with whom players can identify, use of an emotionally appealing fantasy directly linked tot the activity, and use of metaphors, (3) two types of curiosity: sensory curiosity (audio and visual effects) and cognitive curiosity (surprises and constructive feedback) (Baltra, 1990; Kafai, 1997; Lepper \& Malone, 1987; Malone, 1980).

Higher motivation, attention and concentration are related to the perception that an activity is "fun"; that is, visually and cognitively attractive to children. According to Hubbard (1991), the criteria of attractiveness must prevail when designing educational software. 
In this sense, the challenge of video games as an educational tool is to transform the perception of video games from "unproductive" to a resource that takes advantage of the effects on attention, concentration and entertainment, without neglecting instructional aspects. If instructional elements could be combined with the intrinsic interest that children and students have in video games, we could dispose of an important tool for learning and motivation within the classroom (Baltra, 1990). That is, of a mediating tool to assist learning and improve achievement, while having fun.

What learning mechanism lies beneath using video games as instructional tools? The concept of incidental learning suggests various lines of research that may contribute knowledge in order to diminish the gap between learning and playing.

Incidental learning is understood as the acquisition of structures of knowledge in absence of explicit presentation of knowledge, with a semi-conscious intention to learn, applying the underlining rules of such knowledge (Whittlesea \& Wright, 1997). It refers to unintentional or unplanned learning that results from activities not overtly educational and occurs through observation, repetition, social interaction and problem solving during activities that involve implicit meanings (Kerka, 2000). Incidental learning involves elements considered highly effective in formal learning situations (Kerka, 2000). Therefore, the simultaneous presence of both incidental and intentional learning is considered ideal (Cohen, 1967).

Even though the concept of incidental learning is currently related to labor force situations (Kerka, 2000), its extension to the school classroom seems relevant. In this context, studies have found that incidental acquisition of meanings of words while reading children (Shu \& Hua, 1994), was positively related to the strength of contextual support (Konopak, 1987; Shu \& Hua, 1994) and the presence of animated presentations (Rieber, 1990).

The field of incidental learning is closely related to the study of implicit knowledge, memory and learning. Underlying these, is the issue of awareness, attention and the cognitive unconscious. Implicit learning has been proven in artificial grammar and complex cognitive structures (Reber, 1993). Questions still remain, however, as to whether the (un)intentional learning that occurs during formal instruction-semantic-based knowledge of simple cognitive structures during early school years - may be considered a form of incidental learning (Saffran, Newport, Aslin, Tunick, \& Barrueco, 1997), and if so, what its relation is to implicit knowledge and how it can be used more adequately as a valuable instructional tool (e.g. through the use of video games).

\section{Design}

The tool designed and used consisted of a low cost videogame platform with display LCD $160 \times 144$ pixels with four tones, easy to operate and with no special technical support. The prototype was based on and already existing hardware and its external appearance is identical to NINTENDO'S Gameboy. However, both the cartridge and the software were designed and created by the research team (see Fig. 1).

The software contained five programs with contents oriented towards the accomplishment of basic reading decoding skills as well as basic math skills. The games were designed so that:

1. Children's attention was focused on playing and not on learning. Learning contents were an intrinsical part of the game, so that their learning was incidental. 

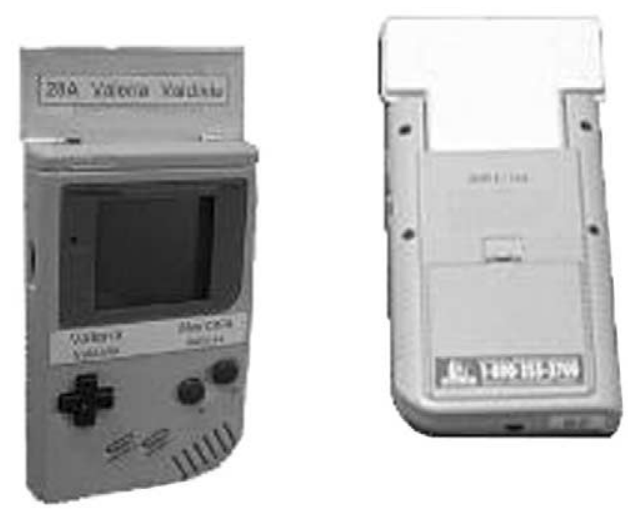

Fig. 1. Prototype of the educational videogame.

2. The contents were organized so that they had an increasing level of complexity, following the school curriculum. They covered all first and second grade reading and mathematics contents of the school curriculum.

3. The games had a progressive and increasing level of difficulty, based on the presentation of antagonists and obstacles. According to the child's performance, the game provided feedback indicating if he or she chose the correct or incorrect answer.

4. The games had a self-regulation system that dynamically adapted the level of difficulty of the contents to the player's learning pace, presenting the player contents based on his or her level of knowledge.

5. The games had an interface and dynamics similar to commercial video games with entertainment purposes.

Table 1 describes the five educational video games designed and implemented in the classrooms, with their respective stories, tasks and educational contents. Fig. 2 shows an example of the esthetical design of these video games.

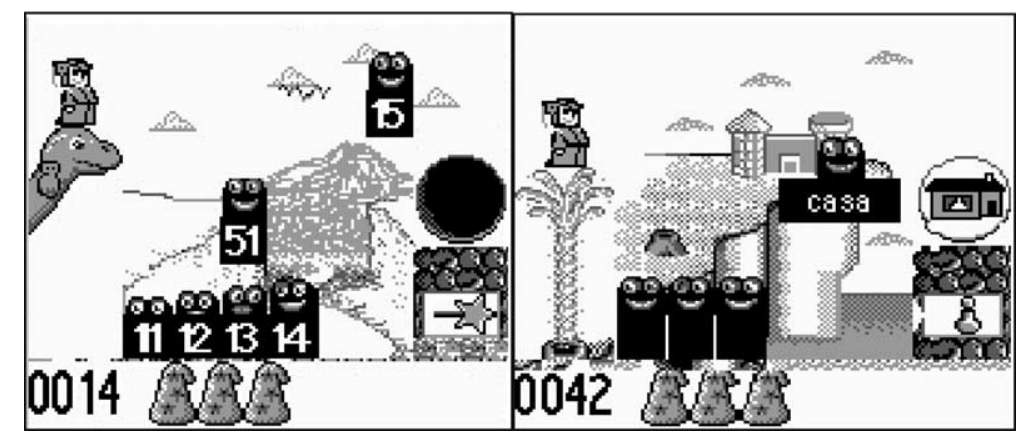

Fig. 2. Example of educational videogame design: Magalú game. 
Table 1

Description of software designed and implemented

\begin{tabular}{|c|c|c|c|}
\hline Name of the Game & Story & Task & Educational contents \\
\hline Magalú & $\begin{array}{l}\text { Magalú is a girl who must use her powers in } \\
\text { order to become a magician, recovering four } \\
\text { objects located in the magic city. While } \\
\text { searching, Magalú must face challenging } \\
\text { characters such as: Gofo, Espiritello, Gómolo, } \\
\text { Frol and McAbro. }\end{array}$ & $\begin{array}{l}\text { Her mission is to throw magic towards } \\
\text { the correct flying blocks, in order to form } \\
\text { a bridge and cross over to conquer the } \\
\text { magic objects. }\end{array}$ & $\begin{array}{l}\text { Language and Communication: Visual } \\
\text { vocabulary, decoding, recognition and } \\
\text { identification of initial syllables and words. } \\
\text { Mathematics: Numeric sequences. }\end{array}$ \\
\hline Hermes & $\begin{array}{l}\text { Hermes, the messenger of the Gods, must } \\
\text { save his friends, the fairies, who are } \\
\text { imprisoned inside the temples of the city. } \\
\text { During the adventure, he must face wicked } \\
\text { Gargoyle and Gods who set up tramps that } \\
\text { impede his entrance into the temples. }\end{array}$ & $\begin{array}{l}\text { In each of the temples, an instruction is } \\
\text { presented with two possible answers. If the } \\
\text { player chooses the correct answer, a fairy } \\
\text { is released and, after completing all the } \\
\text { exercises of a scene, he or she may enter the } \\
\text { next city. }\end{array}$ & $\begin{array}{l}\text { Language and Communication: Identification } \\
\text { of initial phonemes and syllabic analysis of } \\
\text { words. Mathematics: Addition and } \\
\text { subtractions, identification of } \mathrm{t}<,>\text { and }= \\
\text { symbols. }\end{array}$ \\
\hline Tiki-Tiki & $\begin{array}{l}\text { Tiki Tiki is a little monkey who must discover } \\
\text { the mysteries found on stone blocks in the } \\
\text { Amazon jungle. During his journey he must pass } \\
\text { through tempestuous waters and grass that try } \\
\text { to trap him. He must also avoid stepping on } \\
\text { serpents and run from coconut rains. }\end{array}$ & $\begin{array}{l}\text { In each scene, the monkey must jump to } \\
\text { uncover blocks with different tasks and then } \\
\text { choose the correct answers, which allows } \\
\text { him to advance towards the final scenes of } \\
\text { the game. }\end{array}$ & $\begin{array}{l}\text { Language and Communication: } \\
\text { Discrimination of lower and upper case } \\
\text { letters, coding of words in terms of their } \\
\text { phonic elements, word completion. Math: } \\
\text { Counting and estimation of numeric elements. } \\
\text { Addition and subtraction, identification } \\
\text { of }<,>\text { and = symbols. }\end{array}$ \\
\hline Roli & $\begin{array}{l}\text { Roli is a girl who must save her planet from } \\
\text { environmental pollution. To do this, she must } \\
\text { collect seeds and take them to her spaceship, } \\
\text { from which plants grow that allow the } \\
\text { decontamination of her planet. During her } \\
\text { mission, she finds trash and contaminating } \\
\text { elements that try to obstruct her work. }\end{array}$ & $\begin{array}{l}\text { The player must look for seeds placed all } \\
\text { over the spaceship that contain the correct } \\
\text { contents, and place them in tubes that lead } \\
\text { them into the spaceship. }\end{array}$ & $\begin{array}{l}\text { Language and Communication: Decoding and } \\
\text { word identification omitting the final and } \\
\text { initial syllable. Mathematics: Recognition of } \\
\text { geometric figures, addition and subtraction. }\end{array}$ \\
\hline Hangman & No particular story is presented & $\begin{array}{l}\text { This is the traditional game known as } \\
\text { "Hangman". It can be played individually } \\
\text { or in pairs, using a cable that connects two } \\
\text { machines. }\end{array}$ & $\begin{array}{l}\text { Language and Communication: Construction } \\
\text { of words represented by the icon that appears } \\
\text { on the screen. }\end{array}$ \\
\hline
\end{tabular}




\section{Method}

\subsection{Subjects}

The sample was composed of 1274 students attending first and second elementary grade, their 30 school teachers and directors of six schools located in Santiago de Chile (see Table 1). All schools had students of lower socioeconomical backgrounds, three were located in the urban area and three in the rural area. The schools were selected from a pool of schools that in the year 2000 formed part of a national governmental program aimed at improving the quality of education in schools with the lowest national academic achievement. ${ }^{2}$

All schools were paired according to similar indicators: general academic achievement [measured through a national achievement test (SIMCE)], socioeconomic background, rural or urban area and level of vulnerability (measured by the Ministry of Education of Chile). Students were divided according to educational group and placed in either an experimental group (EG), or an internal control group (IC) - groups in the same school and at the same educational level —or in an external control groups (EC) - groups in different schools where the tool was not introduced, but at the same educational level as the EG (see Table 2). This division was constructed with Hawthorn's effect (Clark, 2000) in mind, because this effect had been observed by the research team in previous studies. ${ }^{3}$ In other words, this was done to control for the alteration of behaviors because the subjects were aware of being studied.

Table 3 shows the size of the sample according to their experimental condition. The professional sample was composed of six school directors and 30 school teachers $(21$ from the classes

Table 2

Description of the sample according to experimental condition

\begin{tabular}{lll}
\hline Group & Description & Professionals involved \\
\hline Experimental & $\begin{array}{l}758 \text { students in 19 classes who played experimental video games } \\
\text { during 12 weeks, 20-40 min daily during regular class hours, } \\
\text { alternating between Language and Mathematical contents. }\end{array}$ & $\begin{array}{l}\text { Director, technical superior } \\
\text { and head teachers. }\end{array}$ \\
Internal control & $\begin{array}{l}347 \text { students in nine classes in the same schools as the experimental } \\
\text { group, who did not play video games. The teachers taught regular } \\
\text { classes but knew they were being assessed as internal control group. }\end{array}$ & $\begin{array}{l}\text { Director and technical } \\
\text { superior }\end{array}$ \\
& $\begin{array}{l}169 \text { students belonging to four schools that did not have any } \\
\text { External control with the experiment. }\end{array}$ & - \\
\hline
\end{tabular}

2 Programa P-900 of the Ministry of Education of Chile.

3 (A) "Diseño, Desarrollo y Evaluación de Juegos Educativos Autorregulados en Plataforma Económica y Masiva". Project FONDEF D96I1016, 1996-1999. See Website http://www.ing.puv.cl/sugoi/. (B) "Desarrollo de Producto y Tranferencia Tecnolágica de Juegos Educativos Autorregulados. Project FONTEC 98-1552, 1999-2000. (C) Aprender sin aprender, jugando: Aprendizaje implícito de estructuras sintácticas de la lengua escrita por medio de juegos. Project FONDECYT 1980573, 1998-1999. Available: http://conicyt.cl/bases/fondecyt/proyectos/01/1998/1980573.html. (D) “Aprender Jugando:Diseño e implementation de un videojuego para reforzar el aprendizaje inicial en lectoescritura y matemáticas". Projecto financed by Fundación Andes and Chilectra, 1999-2001. 
Table 3

Size of the sample according to experimental condition and grade level

\begin{tabular}{lccc}
\hline & First & Second & Total \\
\hline Experimental & 379 & 379 & 758 \\
Internal control & 145 & 202 & 347 \\
External control & 85 & 84 & 169 \\
Total & 609 & 665 & 1.274 \\
\hline
\end{tabular}

that formed the experimental group, and nine from the classes that formed the internal control group).

\subsection{Instruments}

In order to assess the effects of video game usage during classes, different instruments were used, aimed at different assessment dimensions.

The main objective was to evaluate the effect of using video games on students' learning, specifically, on the learning of basic Language acquisition skills-Reading Comprehension and Spelling - and Mathematical operations. This was studied using a reading-and-writing and a mathematical test. These instruments were used as pre and posttests in the three groups: experimental, internal control and external control.

In order to identify intervening variables that could explain and differentiate the effects of video game use over learning, several surveys were conducted. These measured the teachers' characterization of students in school and their expectations of change related to the introduction of video games in the classroom, and student motivation towards video games. Teaching quality and social climate in the classroom were studied through observations in classrooms (see Table 4).

\subsection{Procedure}

The implementation and assessment of video games in the classroom was done during the year 2000, in three phases. During the first phase (pre-implementation), informative seminars and reunions were held in which the schools involved in the experimental part of this study participated. Teachers and directors were trained, with respect to the use of the machines, their educational contents, game dynamics of each video game, and implementation procedure. In addition, the assessment system and the timing of its application were explained.

The second phase (implementation) consisted of the incorporation of video games in the experimental groups, as a systematic tool in the teacher's instructional activities. For this implementation, each school counted with a set of machines so that each student could individually play from 20 to 40 min daily, inside the classroom. The machines were shared by different classrooms, which meant they had to be transported from room to room in a suitcase on wheels. In each school, teachers organized their schedules so that all experimental classrooms could play an equal number of hours each week (total average student playing time was $30 \mathrm{~h}$ ). Teachers also planned on the basis of their own judgements which games were played, in accordance with the specific learning needs of the students. During the first two to three sessions, the research team 
Table 4

Description of instruments used, according to subjects aimed, moment of assesment and experimental condition

\begin{tabular}{|c|c|c|c|c|}
\hline Subjects & Instruments & Description & $\begin{array}{l}\text { Moment of } \\
\text { assessment }\end{array}$ & $\begin{array}{l}\text { Experimental } \\
\text { condition }\end{array}$ \\
\hline \multirow[t]{3}{*}{ Students } & $\begin{array}{l}\text { Reading-and-Writing Test } \\
\text { (Seguel, Edwards, Lira, De } \\
\text { Amesti, Atalah, \& Galaz, 1997). }\end{array}$ & $\begin{array}{l}\text { Assesses silent reading comprehension, reading level and writing } \\
\text { of dictations. Allows group application. Contains versions for } \\
\text { first and second elementary grade. Gives partial and total score } \\
\text { that indicate overall average of achievement. }\end{array}$ & Pre and post test & EG IC EC \\
\hline & $\begin{array}{l}\text { Mathematical Test } \\
\text { (designed by the research team) }\end{array}$ & $\begin{array}{l}\text { Assesses reading, writing and ordering of numbers; sign } \\
\text { recognition; addition and subtraction; problem solving and } \\
\text { geometry. Contains versions for first and second elementary } \\
\text { grade and allows group application. }\end{array}$ & Post test & EG IC EC \\
\hline & $\begin{array}{l}\text { Preference Survey } \\
\text { (designed by the research team) }\end{array}$ & $\begin{array}{l}\text { Explores students' preference of video games with respect to } \\
\text { other daily activities, in three moments: during school classes } \\
\text { and recess period. For each moment, the student must choose } \\
\text { his preferences from a variety of activities shown as drawings } \\
\text { (reading stories, doing homework, watching television, playing } \\
\text { video games and playing). The survey allows group application } \\
\text { and informs of the first choice of each student. }\end{array}$ & & \\
\hline \multirow[t]{2}{*}{ Teachers } & $\begin{array}{l}\text { Survey of Change Expectations } \\
\text { (designed by the research team) }\end{array}$ & $\begin{array}{l}\text { Assesses teachers' expectation of change for the school year, with } \\
\text { respect to the incorporation of video games in the classroom, } \\
\text { considering different cognitive and socioaffective dimensions. In } \\
\text { the pretest, teachers must indicate changes expected in general, and } \\
\text { those expected due to the introduction of video games. In the } \\
\text { posttest, teachers must identify positive and negative changes } \\
\text { perceived in the dimensions indicated in the pretest, indicating } \\
\text { whether these are attributed to the incorporation of video games } \\
\text { or to other variables. }\end{array}$ & Pre and post test & EG \\
\hline & $\begin{array}{l}\text { Classroom Observation } \\
\text { Guideline (designed by the } \\
\text { research team based on } \\
\text { guidelines of Arancibia \& } \\
\text { Alvarez, 1991; Seguel, } \\
\text { Correa, \& de Amesti, 1999). }\end{array}$ & $\begin{array}{l}\text { Assesses classroom dynamics (variables: teachers' characteristics, } \\
\text { teaching methodology, group management and students' behavior). } \\
\text { Designed for observation during a } 45 \text {-min class period. Every } 5 \text { min, } \\
\text { the number of students paying attention to the activity is registered. } \\
\text { Gives total and partial score. }\end{array}$ & Post test & EG IC \\
\hline
\end{tabular}

Correa, \& de Amesti, 1999). 
played an active role in the classroom, modeling the use of video games. The rest of the sessions were run by the teacher, with a weekly supervision of one member of the research team.

The third phase (assessment) took place before and after the implementation. In the pretest the instruments, described in Table 4, were used. Towards the end of the implementation, a posttest was conducted. Classroom observations were done by members of the research team, who were trained on its application and held in those schools where they had not participated directly in the implementation of the project. This to achieve a higher interrater reliability. In the experimental group, the observations were done for two different instructional moments, with the use of video games and without its use.

The instruments used in the pretest were applied as posttest at the end of the school year. The same conditions were applied as in the pretest: two evaluators applied the instruments in the absence of the teacher, in small groups of 15 students. Besides the instruments used in the pretest, the preference survey was also applied. In order to facilitate its comprehension, the drawings were accompanied by a verbal explanation of each drawing by a member of the research team. The image of the video game was similar to the commercial format of Nintendo's Gameboy, known by all students, and was explained as "playing video games". This became especially relevant for control groups who had had no direct contact with the video games used in this experiment.

\section{Results}

\subsection{Tool's impact on students' learning ${ }^{4}$}

Separate analyses of covariance were run to test the effect of the intervention on Math, Reading Comprehension and Spelling. For each analysis, pretest scores on the specific subject tested were introduced as covariates in order to control for initial levels of the ability. The results of these analyses are presented in Tables 5-7.

Table 5

Analysis of variance for posttest math, with pretest math as a covariate

\begin{tabular}{lccc}
\hline Source & $d f$ & $F$ & $* *$ \\
\hline MATHPRE & 1 & 1392.15 & $* *$ \\
GROUP & 2 & 10.95 & \\
Error & 1090 & $S E$ & $* *$ \\
Contrast & & & \\
EG-IC & Estimate & 0.429 & 0.574 \\
EC-(EG + IC) $/ 2$ & -2.481 & & \\
\hline
\end{tabular}

MATHPRE = Pretest Math; GROUP = Intervention Group; EG = Experimental group; IC = Internal control; $\mathrm{EC}=$ External control.

** $P<0.01$.

\footnotetext{
${ }^{4}$ The analysis of the variance considering the nested structure of the data showed results that were consistent with the reported analyses of the covariance. ANCOVAS are presented to reduce the complexity of the presentation.
} 
Table 6

Analysis of variance for posttest, with pretests spelling as a covariate

\begin{tabular}{llll}
\hline Source & $d f$ & $F$ & $* *$ \\
\hline SPELLPRE & 1 & 2544.05 & $*$ \\
GROUP & 2 & 5.03 & \\
Error & 1070 & $S E$ & $* *$ \\
Contrasts & Estimate & 0.181 & $* .252$ \\
EG-IC & -0.270 & 0.752 & \\
EC-(EG + IC) $/ 2$ & -0.25 & \\
\hline
\end{tabular}

SPELLPRE $=$ Pretest Spelling; GROUP $=$ Intervention Group; $E G=$ Experimental group; $I C=$ Internal control; $\mathrm{EC}=$ External control.

* $P<0.05$.

** $P<0.01$.

Table 7

Analysis of variance for posttest reading comprehension, with pretest reading comprehension as a covariate

\begin{tabular}{lccc}
\hline Source & $d f$ & $F$ & $* *$ \\
\hline READPRE & 1 & 402.05 & 1.56 \\
GROUP & 2 & \\
Error & 1069 & $S E$ \\
& & 0.214 \\
Contrast & Estimate & 0.299 \\
EG-IC & 0.06 & -0.527 & \\
EC-(EG + IC) $/ 2$ & &
\end{tabular}

READPRE $=$ Pretest Reading Comprehension; GROUP $=$ Intervention Group; $E G=$ Experimental group; $I C=$ Internal control; $\mathrm{EC}=$ External control.

** $P<0.01$.

As can be seen in Table 5, the type of intervention had a significant effect on posttest Math scores, controlling for pretest ability. Planned comparisons showed there was a significant difference between means for children in the experimental schools (either experimental or internal control classes) and the external control group, but no mean differences were found between the experimental and internal control groups. A similar pattern of results was observed for posttest Spelling (see Table 6). For Reading Comprehension (see Table 7) the difference was in the expected direction but was not significant.

\subsection{Tool's impact on students' motivation}

With regard to the students' motivation, two indicators were considered: the results from the preference survey and those from classroom observations.

Results suggest that children were highly motivated to play with video games even at the end of the implementation period, this clearly being the preferred activity compared to the usual pedagogical activities. 
Figs. 3 and 4 (Table 8) show the children's preferences for the possible activities that may be carried out in the classroom. When evaluating the distribution of the preferences in the three groups, a significant association was obtained $\left(\chi^{2}=102,8 ; P<0.001\right)$. Within the classroom environment, children in the experimental schools (either EG or IC) showed more preference for the video game compared to the EC group.

The results from the EC group are more homogeneous; drawing is preferred by a larger percentage. However, this percentage is considerably inferior to those that prefer the video game in the other groups. Note that children from the EC group never had direct nor indirect contact with the experimental video games.

During recess, results are similar to the preceding ones: the preference comes close to statistical significance $\left(\chi^{2}=14,996 ; P<0.059\right)$. While in recess, children in the EC and IC groups preferred the video game slightly over "playing ball", which was the second preference both groups (see Fig. 4).

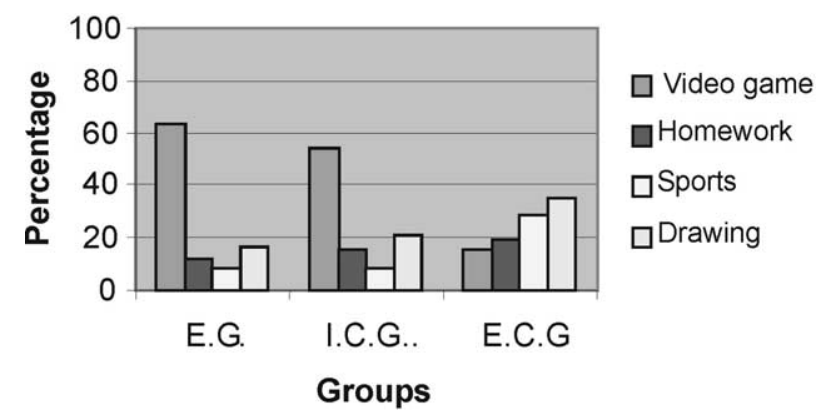

Fig. 3. Preferred activities within the classroom environment.

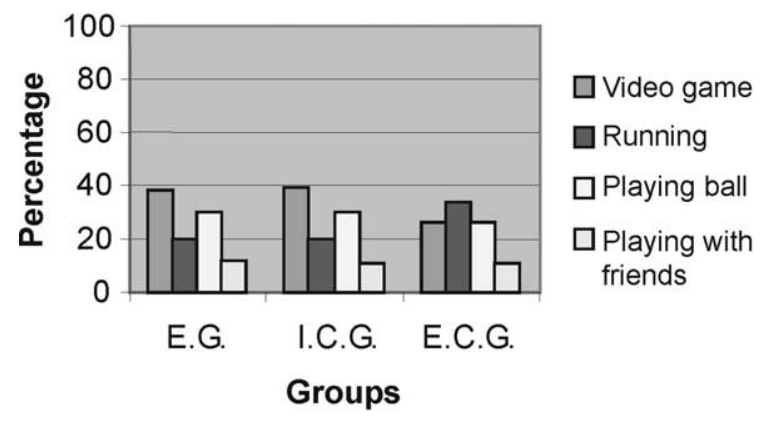

Fig. 4. Preferred activities within the recess environment.

Table 8

\begin{tabular}{llllllll}
\hline $\begin{array}{l}\text { Classroom } \\
\text { environment }\end{array}$ & $\begin{array}{l}\text { E.G. } \\
(n=692)\end{array}$ & $\begin{array}{l}\text { I.C. } \\
(n=289)\end{array}$ & $\begin{array}{l}\text { E.C. } \\
(n=109)\end{array}$ & Recess environment & $\begin{array}{l}\text { E.G. } \\
(n=692)\end{array}$ & $\begin{array}{l}\text { I.C } \\
(n=289)\end{array}$ & $\begin{array}{l}\text { E.C. } \\
(n=109)\end{array}$ \\
\hline Video game & 62.9 & 54.0 & 15.6 & Video game & 37.8 & 38.8 & 26.6 \\
Homework & 12.1 & 15.9 & 19.3 & Running & 19.8 & 20.1 & 33.9 \\
Sports & 8.1 & 8.0 & 28.4 & Playing ball & 30.1 & 30.4 & 26.6 \\
Drawing & 16.5 & 21.1 & 34.9 & Playing with friends & 11.6 & 10.6 & 11.0 \\
\hline
\end{tabular}


Table 9

Percentage of teachers reporting a positive change in the evaluated aspects in relation to their previous expectations

\begin{tabular}{llll}
\hline & $\begin{array}{l}\text { Expectations of } \\
\text { change in pretest (\%) }\end{array}$ & $\begin{array}{l}\text { No expectations of } \\
\text { change in pretest (\%) }\end{array}$ & $\begin{array}{l}\text { Percentage of teachers who } \\
\text { recognized a positive change } \\
\text { in posttest (\%) }\end{array}$ \\
\hline Verbal interaction between students & 50 & 29 & 79 \\
Self-esteem & 64 & 29 & 93 \\
Fellowship & 36 & 43 & 79 \\
Attention and concentration & 79 & 14 & 93 \\
Math performance & 77 & 8 & 85 \\
Language performance & 85 & 8 & 93 \\
Discipline & 72 & 0 & 72 \\
\hline
\end{tabular}

These results confirm and are consistent with the classroom observation records, and are shared by the participating teachers. EG Students both in the first and second grade were observed as visibly happier when the scheduled time for playing arrived, and demanded playing with the experimental video games if there was a delay. The students' demands for the video games was used by teachers as a motivational tool, for example, in order to avoid students arriving late, some teachers scheduled the video game playing hour for the first period of class, which improved punctuality. In other classes, in order to manage tiredness exhibited by students towards the end of the day, the experimental video game was programmed for the last period in order to increase children's motivation, attention and concentration.

In general, children from all EG classes reported that the gaming time seemed for them too short. Teachers shared this opinion, and reported that the games turned out to be so motivating that students developed a greater interest in learning and even a higher motivation in attending school itself.

\subsection{Classroom dynamics}

Classroom observations highlighted important characteristics of class dynamics. Comparing class periods with and without the use of the experimental tool, the percentage of children paying attention while using the experimental tool was significantly higher $(t=-5,21 ; P<0.001)$ and their behaviour more disciplined $(t=4.14 ; P<0.001)$ than during class sessions without their use (see Figs. 5 and 6). This is consistent with the results related to motivation, recently described.

Teacher behavior oriented towards the stimulation of cognitive and verbal development of their students decreased during the classes with experimental video games, because students were more autonomous in guiding their own learning process $(t(\mathrm{df})=4,577 ; P<0.001)$

No differences were observed between EG and IC groups in relation to teacher characteristics, classroom organization, group management and social-affective development support.

\subsection{Technological transfer}

In the context of this study, we understand technological transfer as the appropriation of the new tool by both teachers and students. 


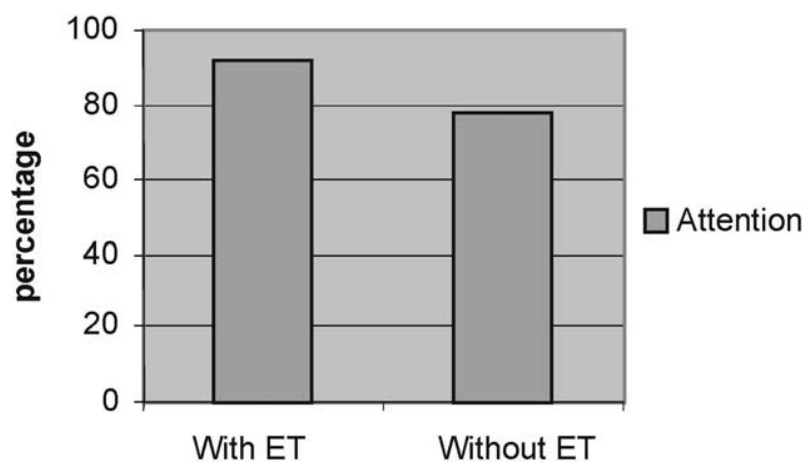

Fig. 5. Average percentage of attention according to experimental condition. ET $=$ Experimental tool.

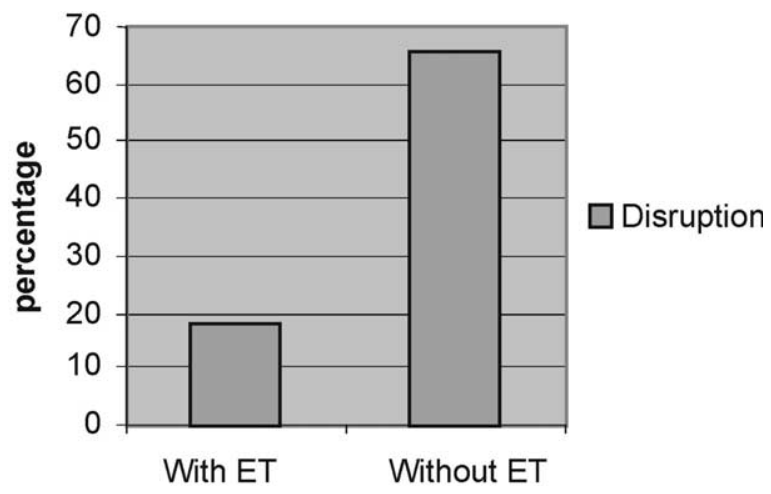

Fig. 6. Average percentage of disruptive behaviour according to experimental condition. ET=Experimental tool.

After the initial training period, teachers adopted different ways of implementing the experimental video games in the classroom: some created dramatizations based on the game stories; others worked with puppets and drawings. All students went through a motivation and game context understanding program, planned by their teacher. According to field records and to the reports given by the teachers themselves, strong teamwork was observed during this process, characterized by the exchange of experiences and mutual support.

Teachers who introduced the experimental tool in the classroom valorized it as an effective resource and as a positive complement to other resources traditionally available to them. Two schools were selected by municipal organizations to present their positive experiences with this new way of teaching and share them with others that were not involved in the study.

The technological appropriation by teachers can be appreciated through the results obtained in the expectations of change record. In the pretest teachers were asked about their expectancies regarding the impact of the experimental tool on different aspects of the children's school behavior; in the posttest they answered questions related to the changes they perceived, considering the same dimensions. Table 9 shows the percentage of teachers who attributed positive effects to the experimental video games, percentages are given for the pretest and in the posttest. 
The aspects in which teachers noticed positive changes are considered of high importance for the learning-teaching process. There was a particularly high percentage of teachers who attributed an improvement in attention and concentration of their students, as well as an increase in selfesteem, to the experimental video games. On all dimensions, except discipline, the percentage of teachers that recognized a positive change in the posttest was higher than the percentage of teachers that expected a change in the pretest. This shows that some of the teachers who beforehand did not think that the introduction of video games in the classroom was going to make a difference, changed their opinion after the experiment, and concluded that the video games had indeed had a positive influence on the teaching and learning environment.

On the other hand, the research team's records and the teacher reports suggest that the experimental video games had a positive impact on promoting peer collaboration, responsibility and perseverance. Even though students liked scoring and excelling within their group, what characterized the game sessions was the support they gave to each other and the strong communication observed with their teachers. As the abilities needed to play were not necessarily related with school content handling, several times low achievers excelled due to their strategic game playing.

In some schools, the easiness with which the children appropriated the tool allowed them to transfer the experience to their peers. To prevent envy and other undesirable reactions from the students in the IC groups, these were offered the video games after the experimental phase was completed. The students from the IC groups rapidly understood the game dynamics, rewards, and incentives given for their right answers, indicating transference of skills and knowledge from their peers in the EG groups. The new players commented on the games with their classmates and teachers, and challenged them to continue playing.

\section{Discussion}

Regarding the effects of video games over initial learning, significant differences were found between the EG and IC groups in relation to the EC group in Math, Reading Comprehension and Spelling.

With regard to the effects on motivation, there are three main indicators that indicate the positive effects of the experimental tool. First, the choice of activities during class and recess periods: during both, students preferred playing the video game over other activities, although the strength of the relationship was stronger within the classroom environment than within the recess period. Second, the positive qualitative assessment from teachers and their use of this tool to motivated the students' attendance and punctuality. Third, the reports indicating that the students increased their concentration and attention while playing with the experimental video game, compared to classroom observations without its use.

Technological transfer was confirmed for both teachers and students; according to research reports and records, there was an adequate and fast appropriation of the technology, which was incorporated in regular classes on a daily basis, without major disarrangement and with a very short period of initial training. Teachers tended to perceive the experimental tool's impact in knowledge areas related to Math and Reading Comprehension, and in motivational areas such as discipline and attention. Teachers reported a positive impact on socio-affective variables related to school achievement such as self-esteem, peer cooperation and student interaction. 


\subsection{Video games and school learning}

To our knowledge, no other studies have been carried out using video games in the school context with the purpose of teaching regular instructional contents. This is surprising, considering that several authors have indicated the need to bring together the world of video games and education (Lepper \& Malone, 1987; Rieber, 1996). Besides studying the harmful effects of violence and gender bias, more scientific studies should focus on the effects of using video games with educational contents.

The results of the present study allow the conclusion that the results of using video games as an educational tool, tend to be more positive than negative.

In terms of the effect on learning, there was a significant difference between students in schools were the experimental tool was introduced (EG and IC groups) and students in the schools that did not. However, no significant difference was proven between the experimental and internal control groups. This result undoubtedly shows the presence of Hawthorn's effect (Clark, 2000), that is, the fact that behaviors may be altered when people know they are being studied. In the case of this study, Hawthorn's effect occurred in a systematic and explicit manner: teachers of the internal control groups were aware of the experiment, and therefore made special efforts to accomplish an adequate performance of their students, sometimes trying to "compete" with achievement in the EG.

It is interesting to note that in the EG the effect of using video games, although not significantly better than the IC groups, was not negative, considering that they used regular instruction periods to implement this experiment. On average, experimental groups played 30 chronological hours during the experiment (half-an-hour of their schoolday, for 12 weeks), time that was taken from their regular instruction in Math and Reading. In other words, these students learned the same as their peers in the control group, in conditions of greater concentration and motivation, and in less stressful conditions for their teachers. Similar results were obtained in a preceding study with 200 children (Rosas, Nussbaum, Condermarín, \& Sun, 2000).

\subsection{Motivational aspects related to video games}

One of the main reasons that lead the research team to design video games according to the school curriculum was to take advantage of its renowned concentration effect over children's motivation (Hubbard, 1991). However, during the initial phase of implementation, there were many concerns from parents and teachers relating to possible addictive behaviors or problems of social isolation as an effect of its use. In summary, teachers' and parents' worries were related to what might be called the psychopathological risks of an "exacerbated motivation".

The reported results give solid evidence for the positive effects of the experimental tool on children's interest and motivation. All results from the preferences survey as well as from classroom observations and teacher reports, allow for the conclusion that children's motivation is assured through the use of video games in the classroom. These results confirm those of previous studies that show high levels of attention and concentration while playing computer games (Kulik, 1994; McFarlane et al., 2002), and specifically, while playing video games (Hubbard, 1991).

With regards to addictive risks or social isolation behaviors (Egli \& Meyers, 1984), two indicators allow us to suggest that these risks are unjustified, at least in relation to the educational 
video games used in this study. First, a drastic decrease of children's preferences for video games during recess was observed, compared to the class period. Second, teachers reported as one of the most unexpected results, its impact on peer cooperation and verbal interaction. This corresponds with the fact that the students were stimulated to share and support each other with hints on how to go to the next stage or how to solve the problems presented in the games. The above counteracts those reports that suggest addictive behavior while playing video games (Ballard \& Wiest, 1995; Cesarone, 1994, 2000; Kirsh, 1997, 1998).

\subsection{Technological transference of video games}

One of the most remarkable and unexpected results of the present study was the fast and positive acceptance by teachers towards the incorporation of the proposed technology. The experimental video games' acceptance in the schools was due, not only to the good disposition that teachers had at the beginning, but above all because of the favorable reception that video games had among the children themselves. For them its use within the classroom was absolutely atypical compared to their expectations of what school is like. Even though some students from the EG had never used a Gameboy, electronic game formats and functions were familiar to all students, and all students learned quickly to use the experimental video games, much faster than their own teachers. This created a new scenario in the teaching-learning process. The above might be explained by the possibility for students to self-regulate their own learning process (Rieber, 1996; Zimmerman, 1990) according to their particular learning styles and speed (Fitzgerald, 1991: Jenkins, 2002) in a manner meaningful to them (Ausubel et al., 1983), thus inverting the hierarchy of knowledge and domain and creating a new technological learning culture (Clark, 1983).

Teachers also began to use the games' metaphors and illustrations of Reading and Math exercises, in their own traditional teaching sessions. Therefore, it was very easy for them to provide a familiar context for the children and in this way motivate learning. As Knezek's found (1997), video games usage had a significant impact, because teachers could integrate the technology in their on ways of teaching.

\subsection{Video games and incidental learning}

An issue that is not completely clear in our results, refers to the learning mechanisms underlying children's learning in a video game context. Given that the task that children face is basically playful, where learning contents are at least covered if not hidden, we believe it is pertinent to suppose that at the base of knowledge acquisition underlie unconscious learning mechanisms, given that the learner's attention is distracted.

In this sense, the concept of incidental learning gives an indication as to how learning through video games occurs. The levels of cognitive consciousness needed in such a learning task is an important issue that needs further study. In the case of learning through traditional methods most levels of consciousness are focussed on the goal to achieve: learning to read and producing written text, or learning to comprehend and apply mathematical exercises. The use of video games as an instructional tool changes the focus from the direct goal of learning, to the direct goal of winning the game, with the indirect goal of learning the words or numbers necessary to 
achieve the goal. This process implies a shift of consciousness, where attention and concentration are given to playing, but nevertheless, allows the acquisition of deep knowledge structures.

Incidental learning shares certain similarities, in terms of the cognitive unconscious, with the concept of implicit learning. Implicit learning has been discovered in adult acquisition of abstract regularities in the structure of artificial grammar (Reber, 1967; Augart, 1994). However, many suppositions but few studies exist about the existence and function of implicit learning in children (cognitive development) and natural grammar (Perruchet, 1998).

Even though we do not have data that allow us to support the existence of implicit learning underlying the cognitive tasks hidden in video games, studies carried out by our research team show auspicious results in this direction. Rosas and Grau (2002) have demonstrated the occurrence of implicit learning with artificial grammars presented to children in a video games modality. They compared three implicit learning paradigms in normal and intellectually retarded children, and showed a significant learning effect using a video game format. Although this evidence is not conclusive, they oblige us to restate the subsystems involved in divided attention tasks, such as those that combine playing and content aspects. We think that future studies in this direction are especially relevant in the context of the elementary education of socioculturally disadvantaged children who lack background environments that allow the appropriate training in the formalities of the school learning context, especially in basic reading and mathematics skills and operations.

\subsection{Video games in education}

The relevance of the results of the present study is even more relevant in the context of general research regarding the use of technologies in education.

Technology in education is mostly understood as computers in the classroom. Though the introduction of computers is appealing and certainly must be promoted, its physical features do not always allow the creation of a technological learning culture centered on student's learning inside the classroom. To obtain such results, many more alternatives must still be examined.

We propose the incorporation of video games, with educational content based on the school curriculum (Rosas, Nussbaum, Grau, López, Salinas, Flores, \& Lagos, 2000). The experience and results of this study prove video games to be a feasible, entertaining, and economic alternative towards taking other technology into the classroom. It is necessary to actively involve the teacher in its implementation, and create the culture necessary to promote effective learning.

The growing development of portable technology for personal use, such as the personal digital assistants (PDAs), could change the future use of technological devices in and for school instruction.

The future of portable technology as an instructional tool — such as a video game - is promising. The challenge is to go beyond Nintendo's Gameboy, taking advantage of the proven positive effects of video games on attention, concentration and self-regulation of students' learning process, and assuring an appropriate transference by the teachers.

\section{Acknowledgements}

The study presented in this article forms part and was financed by the following research and development projects: FONDEF D9611016, FONDECYT 1980573, FONTEC 98-1552, Fundación 
Andes C-13595 and FONDECYT 1000520. We would like to thank Ellen Helsper for her revision of the English version of the paper.

\section{References}

Arancibia,V., \& Alvarez, M. I. (1991). Contrastación de un modelo explicativo del rendimiento escolar en base a las variables del profesor y a su manejo del proceso de enseñanza aprendizaje. Proyecto Fondecyt 0405-88. Santiago, Chile.

Augart, C. (1994). Implicit learning. Psychologial Bulletin, 115(2), 163-196.

Ausubel, D. P., Novak, H., \& Hanesian, H. (1983). Psicología educativa: Un punto de vista cosgnoscitivo. México: Trillas.

Avezedo, R., \& Bernard, R. M. (1995). A meta-analysis of the effects of feedback in computer-based instruction. Journal of Educational Computing Research, 13(2), 111-127.

Baird, W., \& Silvern, S. (1990). Electronic games: Children controlling the cognitive environment. Early Child Development and Care, 61, 43-49.

Ballard, M., \& Wiest, R. (1995). Mortal Kombat: The effects of violent video technology on male's hostililty and cardiovascular responding. Paper presented at the Biennal Meeting of the Society for Research in Child Development, Indianapolis, 30 March - 2 April.

Baltra, A. (1990). Languaje learning through computer adventure games. Simulation and Gaming, 21, 445-452.

Bennet, N., Wood, L., \& Rogers, S. (1997). Teaching through play: Teacher's thinking and classroom practice. Buckingham: Open University Press.

Bruner, J. (1986). El habla del niño: Aprendiendo a usar el lenguaje. Barcelona: Paidós.

Cesarone, B. (1994). Video games and children. ERIC Digest ED365477.

Cesarone, B. (2000). Juegos de videos: Investigación, puntajes y recomendaciones. ERIC Digest ED446825.

Choi, J., \& Hannafin, M. J. (1995). Situated cognition and learning environments: roles, structures and implications for design. Educational Technology Research and Development, 43(2), 53-69.

Clark, D. (2000). Hawthorne effect (On line). Available: http://www.nwlink.com/donclarck/hrd/history.html.

Clark, R. E. (1983). Reconsidering research on learning from media. Review of Educational Research, 53, 445-460.

Cohen, D. (1967). A study of the efficiency of learning when both incidental and intentional learning occur simultaneously. ERID ED 019701.

Coley, R. J., Cradler, J., \& Engel, P. K. (2000). Computers and the classroom: the status of technology in U.S. schools. Princeton, NJ: Policy Information Center, Educational Testing Service.

Csikszentmihaliy, M. (1990). Flow: the psychology of optimal experience. New York: Harper \& Press.

Din, F., \& Caleo, J. (2000). Playing computer games versus better learning. Paper presented at the Annual Conference of the Eastern Educational Research Association, Clearwater, FL, 16-19 February.

Driscoll, M., \& Rowley, K. (1997). Semiotics: toward learning-centered instructional design. In C. R. Dills, \& A. J. Romiszowski (Eds.), Instructional development paradigms (pp. 311-334). Englewood Cliffs, NJ: Educational Technology Publications.

Egli, E., \& Meyers, L. (1984). The role of video game playing in adolescent life: is there reason to be concerned?. Bulletin of the Psychonomic Society, 22(4), 309-312.

Fitzgerald, G. (1991). Using the computer with student with emocional and behavioral disorders. Reston, VA: Council for Excepcional Children, Center for Special Education Technology.

Garret, M. \& Ezzo, M. (1996). Edutainment: The challenge. ERIC EJ524809.

Gros, B. (2000). El ordernador invisible: Hacia la apropiación del ordenador en la enseñanza. Barcelona: Gedisa.

Herrington, J., \& Oliver, R. (1999). Using situated learning and multimedia to investigate higher-order thinking. Journal of Interactive Learning Research, 10(1), 3-24 (http://www.chile-hoy.de/sociedad/000718_brunn_educ.htm).

Hubbard (1991). Evaluating computer games for language learning. Simulation and Gaming, 22, 220-223.

Institute for Learning Sciences (1994). Computer helping schools address natural learning. (On line). Available: http:// www.ils.nwu.edu.

Jenkins, H. (2002). Game theory. Technology Review, 29, 1-3. 
Kafai, Y. (1995). Minds in play: Computer game design as a context for children's learning. Hillsdale, New Jersey: Lawrence Erlbaum Associates.

Kafai, Y. (1997). FONDEF project review. Paper presented to the FONDEF 1016 research team as proyect consultant. Unpublished manuscript.

Keller, S. (1992). Children and the Nintendo. ERIC ED405069.

Kerka, S. (2000). Incidental learning. Trends and alert. ERIC ED446234.

Kestenbaum, G., \& Weinstein, K. (1985). Personality, psychopathology and developmental issues in male adolescents. Journal of the American Academy of Child Psychiatry, 24(3), 329-333.

Kirsh, S. (1997). Seeing the world through "Mortal Kombat" colored glasses: violent video games and hostile attribution bias. ERIC ED413986.

Kirsh, S. (1998). Seeing the world through “Mortal Kombat” colored glasses: violent video games and the development of short-term hostile attribution bias. ERIC EJ567802.

Knezek, G. (1997) Computers in education worldwide: impact on students and teachers. (On line). Available: http:// www.tcet.unt.edu/research/worldwd.htm.

Konopak, B. (1987). Incidental versus intentional word learning from context. Reading Psychology, 8(1), 7-21.

Kulik, J. (1994). Meta-analytic studies of findings on computer-based instruccion. In E. Baker, \& H. O’Neil (Eds.), Technology assesment in education and training. New York: Lawrence Erlbaum Associates, Inc.

Lagos, R. (2002). Presidential speech. Santiago, Chile: National Government.

Lepper, M., \& Malone, T. (1987). Intrinsic motivation and instruccional effectiveness in computer-based education. In R. E. En Snow, \& M. J. Farr (Eds.), Aptitudes, learning and instruction, II: conative, and affective process analysis. Hillsdale, NJ: Lawrence Earlbaum Association.

Lou, Y., Abrami, P., \& d'Apollonia, S. (2001). Small group and individual learning with technology: a meta-analysis. Review of Educational Research, 71(3), 449-521.

Malone, F. (1980). Toward a theory of intrinsically motivation instruction. Cognitive Science, 5(4), 333-369.

Mandinach, E. (1987). Clarifying the "A" en CAI for learners of different abilities. Jounal of Educational Computing Research, 3(1), 113-128.

McFarlane, A., Sparrowhawk, A. \& Heald, Y. (2002). Report on the educational use of games: An exploration by TEEM of the contibution which games can make to the education process. (On line). Available: http://reservoir.cent.uji.es/ canals/octeto/es/440.

Nussbaum, M., Rosas, R., Rodríguez, P., Sun, Y., \& Valdivia, V. (1999). Diseño, desarrollo y evaluaciòn de videojuegos portátiles educativos y autorregulados. Ciencia al Día, 3(2), 1-19.

Papert, S. (1980). Mindstorms: children, computers, and powerful ideas. New York: Basic Books.

Piaget, J. (1951). Play, dreams and imitation in childhood. New York: W. W. Norton \& Company.

Provenzo, E. (1991). Video kids. Cambridge: Harvard University Press.

Provenzo, E. (1992). The video generation. American School Board, 179(3), 29-32.

Provost, J. A. (1990). Work, play and type: Achieving balance in your life. Palo Alto, CA: Consulting Psychologist Press.

Reber, A. (1967). Implicit learning of artificial grammars. Journal of Verbal Learning and Verbal Behaviors, 6, 855-863.

Reber, A. (1993). Implicit learning and tacit knowledge. Oxford: University Press.

Reeves, T. C. (1998). The impact of media and technology in schools. Georgia: The Bertelsmann Foundation.

Rieber, L. (1990). Effects of animated visuals on incidental learning and motivation. Paper presented at the Convention of the Association for Educational Communications and Technology, Texas.

Rieber, L. P. (1996). Seriously considering play: designing interactive learning environments based on the blending of microworlds, simulations and games. Educational Technology Research and Development, 44(2), 43-58.

Rogoff, B. (1993). Aprendices del pensamiento. El desarrollo cognitivo en el contexto social. Barcelona: Paidós.

Rosas, R., \& Grau, V. (2002). Aprendizaje implícito y retardo mental: ¿Un problema de memoria de trabajo?. Revista Estudios Psicológicos.

Rosas, R., Nussbaum, M., Condemarín, M., y Sun, Y. (2000). Implicit learning of an artificial grammar in school age children by means of an electronic game Unpublished manuscript. Santiago de Chile: Pontificia Universidad Católica de Chile.

Rosas, R., Nussbaum, M., Grau, V., López, X., Salinas, M., Flores, P., Correa, M., \& Lagos, F. (2000). Más allá del Mortal Kombat: Diseño y evaluación de videojuegos educativos para Lenguaje y Matemáticas para el Nivel Básico I. Psykhé, 9, 125-141. 
Saffran, J., Newport, E., Aslin, R., Tunick, R., \& Barrueco, S. (1997). Incidental languaje learning: Listening (and learning) out of the corner of your ear. Psychological Science, 8(2), 101-105.

Schank, R. C. (1990). Tell me a story: a new look at real and artificial memory. New York: Scribner.

Seguel, X., Correa, M., \& de Amesti, A. (1999). Pauta de Observación de Prácticas Docentes: Estudio de sus Características Psicométricas. Psykhé, 8(2), 103-110.

Seguel, X., Edwards, M., Lira, M., De Amesti, A., Atalah, E., \& Galaz, H. (1997). Evaluación del impacto de la educación parvularia sobre los niños. Informe final. Santiago de Chile: Documento Ministerio de Educación-CEDEP.

Sivin-Kachala, J., \& Bialo, R. R. (1994). Report on the effectiveness of technology in schools, 1990-1994. ERIC ED 371726.

Soloway, E. (1998). No one is making money in educational software. Communications of the ACM, 41(2), 11-15.

Turkle, S. (1984). The second self: computers and the human spirit. Paris: Denoel.

Vigotsky, L. (1976). Play and its role in the mental development of the child. In J. En Bruner, A. Jolly, \& K. Sylva (Eds.), Play - its role in development and evolution (pp. 537-554). New York: Basic Books.

Vigotsky, L. (1979). El desarrollo de los procesos psicológicos superiors. Barcelona: Crítica.

Whittlesea, B., \& Wright, R. (1997). Implicit (and explicit) learning: acting adaptively without knowing the consequences. Journal of Experimental Psychology, 23, 181-200.

Zimmerman, B. (1990). Self-regulated learning and academic achievement: an overview. Educational Psychologist, 25(1), 3-17. 